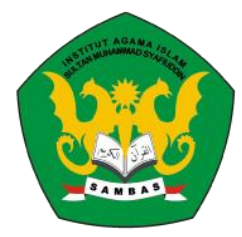

Jurnal Ilmu Komunikasi, Penyuluhan dan Bimbingan Masyarakat Islam Vol. 3, No. 1, Januari 2020 P-ISSN: 2615-3181

\title{
STRATEGI KOMUNIKASI REMAJA MASJID SYUHADA DALAM MELAKUKAN PEMBINAAN AKHLAK REMAJA DI DUSUN MENSEMAT DESA MEKAR JAYA TAHUN 2020
}

\author{
Jepriadi \\ Institut Agama Islam Sultan Muhammad Syafiuddin Sambas \\ jjepriadi1@gmail.com \\ Azwar \\ Institut Agama Islam Sultan Muhammad Syafiuddin Sambas \\ azwar532@gmail.com
}

\begin{abstract}
Islamic preaching is an activity of communicating the teachings of Allah Almighty which are contained in the Al-Quran and Sunnah, so that people can take it as their way of life. Given the many problems that occur among adolescents, ranging from moral and moral crises. To overcome this problem, of course there is a training that is carried out. In the process of coaching adolescents, special abilities are needed. One of them is the communication strategy carried out in the youth coaching process. The purpose of this study in general is to find out the communication strategies of the Syuhada mosque youth in conducting adolescent morals development in the Mensemat Hamlet, Mekar Jaya Village. Whereas specifically, knowing the communication planning and communication management carried out by the teenagers of the Syuhada mosque in developing youth morals in the Dusun Mensemat, Mekar Jaya Village, and knowing the supporting and inhibiting factors for the success of the Syuhada mosque youth communication strategy in developing youth morals in the Mensemat Village Mekar Jaya Village. This type of research is descriptive qualitative research. In this study, the data consisted of primary and secondary data. The data collection techniques are observation, interview, and documentation techniques. The data analysis technique used was data reduction, data presentation, verification and conclusion drawing. After being analyzed, the validity of the data is tested by mamber check, and triangulation. The conclusions of the results of the research ari: Communication planning carried out by teenagers of the Syuhada mosque in adolescent moral development in Menemat Village, Mekar Jaya Village is in the form of determining activities in adolescent morality development, determining messages to provide guidance, and selecting media in the process of building morals for adolescents, Communication management that is carried out is planning and evaluating the communication strategy undertaken. Supporting factors and obstacles to the success of the Syuhada Mosque youth communication strategy are in the form of external and internal Tractors including adequate facilities and infrastructure, inadequate use of time, adolescents who are difficult to provide guidance, poor signal quality in conveying messages, and parents.
\end{abstract}

Keyword: Communication Strategy, Mosque Youth, Moral Development. 


\begin{abstract}
ABSTRAK
Dakwah agama Islam merupakan kegiatan mengkomunikasikan ajaran Allah swt yang terkandung dalam Al-Quran dan As-Sunnah, agar manusia mengambilnya untuk menjadi jalan hidupnya. Mengingat banyak permasalahan yang terjadi di kalangan remaja, mulai dari krisis moral dan akhlak. Untuk mengatasi permasalahan tersebut tentu adanya sebuah pembinaan yang dilakukan. Dalam proses pembinaan terhadap remaja diperlukan kemampuan khusus. Salah satunya adalah strategi komunikasi yang dilakukan dalam proses pembinaan remaja. Adapun tujuan dari penelitian ini secara umum yakni mengetahui strategi komunikasi Remaja masjid Syuhada dalam melakukan pembinaan akhlak remaja di Dusun Mensemat Desa Mekar Jaya. Sedangkan secara khusus yakni mengetahui perencanaan komunikasi dan manajemen komunikasi yang dilakukan oleh remaja masjid Syuhada dalam pembinaan akhlak remaja di Dusun Mensemat Desa Mekar Jaya, serta mengetahui faktor pendukung dan penghambat keberhasilan dari strategi komunikasi remaja masjid Syuhada dalam pembinaan akhlak remaja di Dusun Mensemat Desa Mekar Jaya. Jenis penelitian ini adalah penelitian kualitatif deskriptif. Dalam penelitian ini, datanya terdiri dari data primer dan sekunder. Adapun teknik pengumpulan data adalah dengan teknik observasi, wawancara, dan dokumentasi. Teknik analisis data yang digunakan adalah reduksi data, penyajian data, verifikasi dan penarikan kesimpulan. Setelah dianalisa, data tersebut di uji keabsahannya dengan mamber cek, dan triangulasi. Kesimpulan dari hasil penelitian adalah 1) Perencanaan komunikasi yang dilakukan oleh remaja masjid Syuhada dalam pembinaan akhlak remaja di Dusun Mensemat Desa Mekar Jaya adalah dalam bentuk menentukan kegiatan dalam pembinaan akhlak remaja, menentukan pesan untuk memberikan pembinaan, dan memilih media dalam proses pembinaan akhlak terhadap remaja, 2) Manajemen komunikasi yang dilakukan adalah perencanaan dan pengevaluasian dari strategi komunikasi yang dilakukan. 3) Faktor pendukung dan penghambat keberhasilan dari strategi komunikasi remaja Masjid syuhada adalah berupa faktor eksternal dan internal di antaranya sarana dan prasarana yang memadai, kurang dalam memanfaatkan waktu, remaja yang sulit diberikan bimbingan, kualitas sinyal yang kurang dalam menyampaikan pesan, serta orang tua.
\end{abstract}

Kata Kunci: Strategi Komunikasi, Remaja Masjid, Pembinaan Akhlak.

\title{
PENDAHULUAN
}

Manusia menyandang predikat sebagai makhluk sosial karena manusia adalah makhluk yang saling berinteraksi dengan orang lain. Adanya jalinan komunikasi dengan orang lain tentu akan memudahkan aktivitas sehari-hari baik dalam kehidupan keluarga, sosial maupun kelompok. Kemampuan dan keinginan berinteraksi inilah yang kemudian melahirkan organisasi-organisasi yang didirikan untuk mencapai tujuan bersama. Pencapaian organisasi tersebut sangat tergantung pada manusia sebagai elemen terpenting dalam sebuah organisasi (Resyana Wilda, 2014). Strategi komunikasi yang baik sangat diperlukan di dalam suatu kegiatan baik itu individu dengan lainnya maupun dalam organisasi. Namun interaksi yang dilakukan di antara satu dengan yang lainnya haruslah dilaksanakan secara harmonis, dinamis, dan pasti untuk mencapai tujuan dari adanya perubahan sosial ke arah positif. 
Selo Soemardjan mengatakan perubahan sosial adalah segala perubahan pada lembaga masyarakat di dalam suatu masyarakat, yang mempengaruhi sistem sosialnya, termasuk di dalamnya nilai-nilai, sikap, perilaku, di antara kelompok-kelompok dalam masyarakat (Soerjono Soekanto, 2003: 305). Pertentangan menjadi sebab terjadinya perubahan sosial. Pertentangan demikian itu sering terjadi, bisa terjadi antara individu dengan individu atau kelompok dengan kelompok lain di masyarakat yang sedang berkembang. Generasi muda yang belum terbentuk kepribadiannya, lebih mudah menerima unsur-unsur kebudayaan asing. Keadaan tertentu menimbulkan perubahan tertentu dalam masyarakat, misalnya pergaulan bebas antara wanita dengan pria atau perkelahian. Perubahan yang terjadi pada masyarakat terutama dalam kalangan remaja merupakan gejala yang normal. Pengaruhnya bisa berjalan dengan cepat yang disebabkan adanya komunikasi modern dan teknologi yang semakin berkembang terutama dalam media sosial.

Perubahan sosial ke arah negatif yang terjadi di Indonesia tergolong cukup tinggi. Terbukti hampir sebagian besar di Indonesia para Remajanya mengalami perubahan sosial ke arah negatif. Berdasarkan pengamatan peneliti pada beberapa media salah satunya di internet (Detik.com) ditemukan kasus yang dilakukan oleh Remaja dalam sehari mencapai dua atau tiga kasus di antaranya Janjian Tawuran Via Medsos Seorang Remaja Di Jakpus Tewas Dibacok dan Wanita Pukul Pacarnya Yang Ketahuan Ambil Foto Tak Senonohnya Diam Diam. Adapun wilayah yang kronis terhadap perubahan sosial ke arah negatif tersebut yakni di daerah tertinggal.

Definisi daerah tertinggal adalah deskripsi dari daerah Kabupaten atau Kecamatan yang masyarakat serta wilayahnya relatif kurang berkembang dibandingkan dengan daerah lain. Daerah dikatakan tertinggal apabila memenuhi enam kriteria dasar, yaitu perekonomian masyarakat rendah, sumber daya manusia rendah, infrastruktur yang kurang memadai, kemampuan keuangan masyarakat lokal rendah, akses menuju daerah tersebut masih sulit dan jauh dari pusat kota, serta karakteristik daerahnya yang masih terbelakang (Bob Andrian, 2017). Daerah yang tertinggal merupakan salah satu wilayah yang cukup strategis dalam melakukan berbagai macam tindakan menyimpang. Kondisi tersebut diakibatkan karena posisi daerah tertinggal jauh dari pengawasan keamanan seperti pengawasan dari oknum Polri, sehingga memberikan kebebasan bagi para Remaja dan anak-anak untuk bertindak sebebas bebasnya. Aspek yang menjadi pengaruh utama saat ini yakni lingkungan. Lingkungan juga salah satu unsur yang menyebabkan semakin maraknya perubahan sosial ke arah negatif yang dilakukan di daerah tertinggal.

Kecamatan Sajad merupakan salah satu daerah yang jauh dari kota, sehingga dilihat dari geografisnya Kecamatan Sajad merupakan wilayah yang menjadi penghubung antara Kecamatan Sejangkung dengan Kecamatan Sambas untuk menjembatani kedua kecamatan tersebut maka Desa Mekar Jaya yang menjadi penghubungnya. Secara geografis Desa Mekar Jaya adalah daerah yang berada di posisi paling tengah di Kecamatan Sajad. Ada dua dusun yang sangat strategis yang menjadi penghubung, di antaranya Dusun Mensemat dan Dusun Kadai.

Berdasarkan pernyataan dari Kepala Dusun Mensemat, menyebutkan bahwa daerah Kecamatan Sajad khususnya Desa Mekar Jaya masuk kategori daerah yang paling sering melakukan tindakan menyimpang sehingga menimbulkan perubahan sosial ke arah negatif. 
Perubahan sosial sering berjalan secara konstan dan terikat dengan waktu maupun tempat baik berupa perubahan sosial yang lambat atau perubahan sosial yang cepat. Terbukti dari beberapa kejadian yang terjadi di tahun sebelumnya, misalnya maraknya pergaulan bebas dilakukan oleh remaja yang berujung semakin meningkatnya pernikahan usia dini. Selain itu adanya kasus perkelahian yang terjadi antar remaja (Hamzani, 2020). Perubahan sosial yang terjadi pada kalangan remaja ini terutama di Dusun Mensemat Desa Mekar Jaya sangat memprihatinkan. Apabila tidak tanggap untuk menanganinya akan berakibat fatal dan semakin rusaknya para remaja serta dapat merusak kepada tindakan-tindakan kejahatan moral yang lain seperti pencurian.

Berdasarkan permasalahan di atas terkai dengan perubahan sosial ke arah negatif di kalangan remaja khususnya di Dusun Mensemat Desa Mekar Jaya peneliti menemukan adanya upaya untuk memberikan pembinaan remaja yang dilakukan oleh organisasi remaja masjid Syuhada. Upaya tersebut dilakukan dalam beberapa bentuk kegiatan yang dilakukan secara rutin. Bentuk kegiatan yang berhasil diamati oleh peneliti di antaranya adalah mengajak remaja yang ada di Dusun Mensemat untuk mengembangkan keahlian yang dimiliki, mengikutsertakan remaja dalam kegiatan zikiran dan yasinan. Selain itu juga memberikan pemahaman kepada remaja dalam membentengi dirinya agar tidak melakukan perbuatan menyimpang.

Remaja masjid adalah sebuah organisasi yang dibentuk oleh masyarakat dan bergerak di bidang keagamaan. Kaitan antara remaja masjid dengan masyarakat adalah organisasi yang bertugas dalam masyarakat di bidang pembinaan dan sosial. Menurut Zakiah Derajat pembinaan adalah upaya pendidikan baik formal maupun nonformal yang dilaksanakan secara sadar, berencana, terancang, teratur dan bertanggung jawab dalam rangka memperkenalkan, menambahkan, mengembangkan suatu dasar kepribadian yang seimbang dan utuh (Zakiah Derajat, 1976: 36). Selain itu, remaja masjid juga berfungsi untuk mempererat tali silaturahmi serta memberikan perlindungan, pembinaan, pengembangan remaja maupun masyarakat. Semua itu dilakukan dalam rangka mewujudkan keamanan, mengurangi perubahan sosial ke arah negatif maupun menciptakan masyarakat yang paham akan nilai-nilai keagamaan.

Remaja masjid harus ikut bekerja dalam mewujudkan masyarakat yang beradab dan berilmu yang menjunjung tinggi sosial, moral, akhlak, dan nilai nilai-nilai agama. Masyarakat akan sadar untuk menjaga dan bersama-sama membentuk masyarakat yang aman dan mengerti nilai-nilai agama terutama dalam hal mengembangkan akhlak. Tindakan-tindakan itulah yang saat ini dilakukan oleh remaja masjid Syuhada Desa Mekar Jaya.

Kegiatan Remaja Masjid menjadi berbeda ketika dihadapkan dengan berbagai kondisi tak terkecuali, seperti kondisi geografis, sosial, budaya, ekonomi, pendidikan dan tingkat kesadaran keagamaan masyarakat yang rendah. Kondisi tersebut tentu akan berdampak pada proses pembinaan akhlak, sehingga strategi komunikasi yang diterapkan juga pasti berbeda.

Strategi komunikasi pada hakikatnya adalah perencanaan (planning) dan manajemen (management) untuk mencapai suatu tujuan. Strategi komunikasi ini merupakan salah satu tahapan yang ada dalam rangkaian aktivitas komunikasi yang berbasis pada satuan teknik dalam mewujudkan tujuan komunikasi (Onong Uchjana Effendy, 2006: 32). Strategi komunikasi akan memiliki dampak positif apabila strategi komunikasi yang dilakukan bisa mewujudkan tujuan dari suatu organisasi yaitu masyarakat sebagai sasaran. Strategi dalam 
komunikasi harus ditentukan dengan baik karena penentuan efektif atau tidaknya dalam komunikasi ditentukan oleh strategi yang digunakan.

Organisasi remaja masjid berupaya meningkatkan aktivitas pengalaman akhlaknya lewat masjid (Moh. E. Ayub, 1996: 152). Melalui organisasi remaja masjid, remaja dapat meningkatkan akhlak dan mendapat lingkungan yang bernuansa Islam, selain itu Remaja Masjid memiliki tugas yaitu dengan cara mengajak Remaja untuk tidak terlibat dalam perubahan sosial ke arah negatif. Sebagaimana Allah swt berfirman:

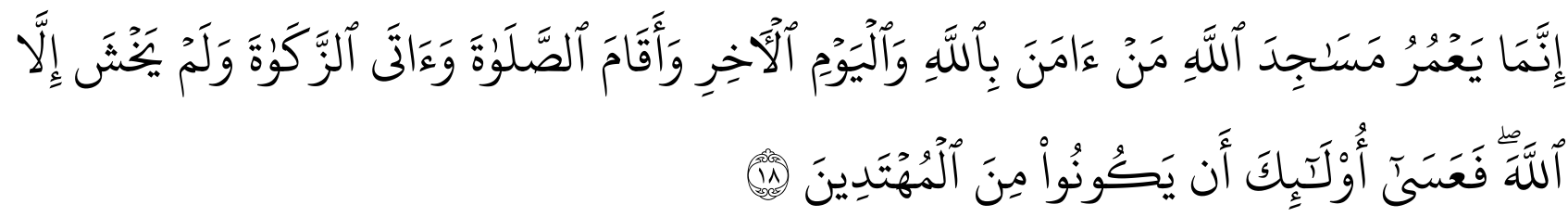

Terjemahnya: "Sesungguhnya yang memakmurkan masjid Allah hanyalah orang-orang yang beriman kepada Allah dan hari kemudian, serta (tetap) melaksanakan sholat, menunaikan zakat dan tidak takut (kepada apapun) kecuali kepada Allah swt. Maka mudah-mudahan mereka termasuk orang-orang yang mendapatkan petunjuk." (Q.S. At-Taubah [9]: 18). (Kementrian Agama, 2019: 189).

Berdasarkan ayat di atas, M. Quraish Shihab menafsirkan bahwa kaum musyrikin tidak wajar memakmurkan masjid Allah swt, yang wajar memakmurkannya yaitu hanyalah yakni tidak lain kecuali siapa yang beriman dengan benar kepada Allah swt dan hari kemudian, serta tetap mendirikan sholat secara tekun dan benar, menunaikan zakat dengan sempurna dan tidak takut kepada siapa pun kecuali kepada Allah swt. Maka mereka itulah yang sangat jauh lagi tinggi kedudukannya adalah orang-orang yang diharapkan termasuk golongan orang-orang yang mendapat serta melaksanakan secara sempurna petunjuk Allah swt (M. Quraish Shihab, 2002: 523).

Remaja harus selalu di berikan pembinaan terkait dengan akhlak yang ada dalam diri. Masih banyak remaja yang masih belum memiliki akhlak yang baik dan moral yang kurang dan kehidupan saat ini terutama pada zaman modern, bahkan masih ada yang melakukan penyimpangan sosial yang menyebabkan perubahan sosial ke arah negatif seperti pergaulan bebas dan perkelahian di kalangan remaja. Oleh karena itu pembinaan yang dilakukan oleh remaja masjid Syuhada sudah semestinya di lakukan dengan tujuan agar dapat meningkatkan pemahaman dan kepatuhan remaja terutama pada sisi akhlak. Remaja akan sukses dan berhasil apabila mempunyai akhlak, keimanan yang baik, mampu menguasai pengetahuan dan teknologi. Namun apabila Remaja tidak memiliki akhlak, keimanan yang kurang maka Remaja tidak meraih prestasi hidup dan justru merusak moral remaja sebayanya.

Upaya yang dilakukan oleh remaja masjid Syuhada dalam membina akhlak yakni dengan menginspirasi para remaja untuk mendapatkan prestasi dalam kegiatan-kegiatan salah satu kegiatan yang dilaksanakan dan memicu prestasi para remaja yakni membuat kegiatan porseni antar organisasi remaja masjid se-Kecamatan Sajad. Dusun Mensemat adalah salah satu dusun di desa Mekar Jaya yang memiliki Organisasi remaja masjid. Oleh karena itu, remaja masjid Syuhada ikut serta dalam kegiatan porseni tersebut. Hasilnya remaja yang ada di Dusun Mensemat sudah mulai memiliki akhlak yang baik, berkurangnya perubahan sosial ke arah 
negatif serta bisa mengembangkan keahlian yang ada. Hal ini dibuktikan dengan berkurangnya pergaulan bebas dan perkelahian serta para Remaja mulai mengenal nilai-nilai agama.

Berdasarkan uraian di atas penelitian tentang strategi komunikasi remaja masjid Syuhada dalam melakukan pembinaan akhlak remaja di Dusun Mensemat Desa Mekar Jaya sangat menarik untuk diteliti, terutama terkait dengan upaya remaja masjid Syuhada dalam melakukan pembinaan kepada Remaja dan memiliki keunikan-keunikan yang belum terdapat di penelitian penelitian yang lain.

Upaya strategi komunikasi tersebut merupakan tugas yang menjadi standar kegiatan pembinaan baik itu di kalangan remaja atau semua lapisan masyarakat. Penelitian ini diharapkan memberikan kontribusi bagi perkembangan di daerah Dusun Mensemat khususnya dan di daerah lain umumnya. Mengingat peran remaja Masjid dalam melakukan pembinaan kepada remaja merupakan upaya yang sangat penting dalam menunjang perkembangan di masyarakat.

\section{METODE PENELITIAN}

Penelitian ini dilakukan menggunakan penelitian kualitatif dengan tujuan memahami kejadian tentang apa yang dialami oleh subjek penelitian misalnya perilaku, persepsi, motivasi, tindakan, dan lain sebagainya. Dengan cara deskripsi dalam bentuk kata-kata dan bahasa, pada suatu konteks khusus yang alamiah dan dengan memanfaatkan berbagai metode alamiah (Lexy J. Moleong, 2009: 6). Menurut John W. Cresswell dalam metode penelitian misalnya Arikunto (2010: 271), menjelaskan bahwa ada tiga langkah yang dapat digunakan oleh peneliti dalam mengumpulkan data.

Adapun di antaranya sebagai berikut, Pertama, observasi yang digunakan sebagai suatu pengamatan yang dilakukan secara langsung kepada objek yang akan diteliti, pengamatan ini meliputi fenomena-fenomena sosial dengan gejala-gejala untuk kemudian dilakukan pencatatan (Djoko Subagyo, 1991: 63). Melalui observasi ini didapatkan informan yang benarbenar tepat untuk dapat digali informasinya lebih dalam berkaitan dengan pembahasan yang akan dicari.

Kedua, wawancara (interview) adalah suatu teknik pengumpulan data yang dilakukan dengan tanya jawab secara lisan, baik langsung atau tidak langsung dengan sumber data responden (terwawancara). (Sanapiah Faisal, 192: 213). Ketiga, teknik dokumentasi merupakan cara pengumpulan data melalui buku-buku tentang teori, arsip dan data lainnya yang berhubungan dengan penelitian untuk melengkapi data yang telah ada, metode dokumentasi digunakan untuk mencari data sekunder. Teknik analisis data penelitian kualitatif digunakan melalui tiga kegiatan dalam penelitian, adapun tiga kegiatan tersebut yakni reduksi data, penyajian data, dan verifikasi sekaligus penarikan kesimpulan. Data primer dalam penelitian ini diperoleh dari Informan yang bernama Manda Saputra sebagai ketua Remaja Masjid Syuhada dan pihak pihak yang melakukan pembinaan akhlak kepada remaja di Dusun Mensemat Desa Mekar Jaya Kecamatan Sajad. 


\section{HASIL DAN PEMBAHASAN}

\section{Strategi Komunikasi}

\section{Pengertian Strategi Komunikasi}

Menurut pakar komunikasi yaitu Effendy mendefinisikan strategi pada hakikatnya adalah perencanaan dan manajemen untuk mencapai tujuan, namun untuk mencapai tujuan tersebut, strategi tidak berfungsi sebagai jalan yang hanya memberikan arah saja, melainkan harus mampu untuk menunjukkan teknik operasionalnya (Onong Uchjana Effendy, 2006: 32). Sedangkan komunikasi adalah proses penyampaian suatu pesan oleh seseorang kepada orang lain untuk memberi tahu atau mengubah sikap, pendapat atau perilaku baik secara langsung atau tidak langsung (Onong Uchjana Effendy, 2008: 5). Strategi komunikasi merupakan kegiatan yang paling penting dalam sebuah organisasi dengan cara mengembangkan tujuan, mengenali peluang dan ancaman atau menetapkan kekuatan dan kelemahan baik itu secara eksternal maupun internal. Adapun dimensi dari strategi komunikasi menurut Effendy adalah sebagai berikut:

a. Perencanaan komunikasi

Suatu perencanaan yang baik adalah perencanaan yang digunakan sebagai pedoman yang baik kemudian mempermudah dalam pelaksanaan kegiatan. Sondang P. Siagian mendefinisikan perencanaan sebagai keseluruhan proses pemikiran dan penentuan secara matang dari hal-hal yang akan dikerjakan pada masa akan datang dalam rangka pencapaian tujuan yang telah ditentukan sebelumnya (Yusuf Zainal Abidin, 2015: 86). Assifi dan French merumuskan langkah-langkah perencanaan komunikasi yang lebih sederhana yaitu menganalisis masalah, menganalisis khalayak, merumuskan tujuan komunikasi, memilih media komunikasi, dan mengembangkan pesan (Yusuf Zainal Abidin, 2015: 96).

b. Manajemen komunikasi

Setiap aktivitas komunikasi tujuannya adalah untuk menyampaikan pesan atau informasi. Untuk mencapai keberhasilan dalam aktivitas tersebut selalu memerlukan yang namanya manajemen. Perencanaan merupakan proses pemanfaatan dari fungsi perencanaan, pengorganisasian, pengarahan, dan pengawasan. Parag Diwan mendefinisikan manajemen komunikasi sebagai proses penggunaan berbagai sumber daya komunikasi secara terpadu melalui proses perencanaan, pengorganisasian, pelaksanaan, dan pengontrolan unsur-unsur komunikasi untuk mencapai tujuan yang ingin dicapai (Yusuf Zainal Abidin, 2015: 131-132).

Strategi komunikasi merupakan perpaduan antara perencanaan komunikasi dan manajemen untuk mencapai suatu tujuan. Untuk mencapai itu semua, strategi komunikasi harus dapat menunjukkan bagaimana operasionalnya secara teknis harus dilakukan, dalam arti bahwa pendekatan bisa saja berubah sesuai situasi dan kondisi. Dengan demikian, strategi komunikasi merupakan keseluruhan perencanaan, teknik dan cara yang akan dilakukan untuk melaksanakan komunikasi dengan menyampaikan informasi dengan memperhatikan aspek yang ada untuk mencapai tujuan yang diinginkan. Rumusan langkah- 
langkah dalam strategi komunikasi terdiri dari beberapa aspek berikut (Onong Uchjana Effendy, 2008: 141-165) :

a. Menetapkan komunikator

Komunikator mempunyai peranan yang sangat penting dan menjadi sumber utama dalam kegiatan komunikasi dan menentukan sukses atau tidaknya suatu komunikasi. Ada beberapa hal yang harus diperhatikan oleh komunikator dalam menyampaikan pesan, yaitu: menguasai pesan yang ingin disampaikan, mampu membuat intonasi serta bahasa tubuh yang mudah dimengerti, mampu menarik perhatian dan mengurangi rasa bosan pada sasaran komunikasi, mampu menyampaikan argumen secara logis yang disertai fakta dan pendapat untuk mendukung pesan yang disampaikan.

b. Menetapkan khalayak sasaran

Ada tiga aspek yang bisa digunakan untuk menetapkan karakteristik masyarakat yang menjadi sasaran, yakni:

1) Aspek sesiodemografik, yaitu mencakup aspek jenis kelamin, usia, pekerjaan, pendidikan, agama, etnis dan lain sebagainya.

2) Aspek profil psikologis, mencakup aspek sikap yang ada dari kejiwaan masyarakat, contohnya masyarakat yang sabar, tenang, berani dan lain sebagainya.

3) Aspek karakteristik perilaku masyarakat, yaitu mencakup dalam kehidupan masyarakat seperti masyarakat santun, tenggang rasa dan lain sebagainya.

c. Menyusun pesan

Penyusunan pesan dalam kegiatan komunikasi ada dua bentuk yang bisa digunakan, yaitu: On side issue, penyusunan pesan yang hanya memperlihatkan atau memberikan tekanan dari salah satu sisi saja baik itu kebaikan atau keburukan dan Two ide issue, pesan yang menonjolkan sisi kebaikan sekaligus keburukan.

d. Pemilihan dan penggunaan media

Media atau saluran yang digunakan dalam komunikasi untuk menyampaikan pesan atau informasi ada beberapa bentuk, yaitu:

1) Media format kecil, yaitu media yang biasanya terdiri atas berbagai media yang mudah dibawa dan mudah menarik perhatian orang banyak. Misalnya pamflet, brosuer, poster, baju dan lain sebagainya.

2) Komunikasi kelompok, yaitu media komunikasi yang dibangun memalui hubungan sosial seperti, pengajian, dzikiran, pramuka, dan lain sebagainya.

3) Komunikasi publik, yaitu media komunikasi yang dilakukan dalam bentuk terbuka seperti turnamen olahraga, kegiatan yang bernuansa Islam, perkawinan dan lain sebagainya.

4) Komunikasi antar pribadi, yaitu suatu bentuk komunikasi yang berlangsung secara tatap muka atau menggunakan media, contohnya sms, telepon, chat, komunikasi dengan sahabat dekat dan sejenisnya.

5) Internet, merupakan sebuah komunikasi berlangsung dengan memanfaatkan jaringan internet yang menghubungkan di seluruh dunia dan terkoneksi sehingga dapat berkomunikasi atau bertukar informasi tanpa dibatasi jarak, waktu, dan tempat. 
e. Menganalisis efek komunikasi

Pengaruh dan efek yang terjadi dalam proses komunikasi sangat penting dengan tujuan untuk mengetahui berhasil atau tidaknya kegiatan komunikasi. Efek yang terjadi dan diterima khalayak sasaran bisa dalam tiga bentuk, yaitu:

1) Perubahan pengetahuan, yaitu perubahan yang bisa berupa persepsi dan pendapat tentang sesuatu.

2) Perubahan sikap, yaitu bisa dalam bentuk perubahan prinsip atau kepercayaan tentang sesuatu.

3) Perubahan perilaku, yaitu perubahan yang terjadi dalam bentuk tindakan.

\section{Strategi Komunikasi Remaja Masjid Dalam Membina Akhlak Remaja Di Dusun Mensemat Desa Mekar Jaya}

1. Perencanaan komunikasi yang dilakukan oleh remaja masjid Syuhada dalam pembinaan akhlak remaja di Dusun Mensemat Desa Mekar Jaya

Perencanaan komunikasi dalam kegiatan pembinaan akhlak remaja pada hakikatnya merupakan serangkaian bentuk kegiatan yang menggambarkan strategi komunikasi antara remaja masjid Syuhada dengan remaja yang dibina. Selanjutnya, strategi komunikasi inilah yang disebut dengan perencanaan komunikasi khususnya kegiatan remaja masjid Syuhada dalam membina remaja di Dusun Mensemat Desa Mekar Jaya. Remaja masjid pada umumnya adalah pihak yang memberikan pembinaan kepada kepada seseorang atau kelompok dalam kasus ini yaitu remaja yang mengalami persoalan dalam hidupnya. Peran remaja masjid tidak sebatas persoalan keagamaan semata. Melainkan, remaja masjid memiliki tanggung jawab lainnya yaitu tanggung jawab moral dan sosial remaja yang dibinanya dari berbagai ancaman, gangguan dan hambatan yang merusak akhlak dan merugikan.

Mengingat kondisi Dusun Mensemat di Kecamatan Sajad adalah daerah yang sering sekali terjadi kasus-kasus mulai dari kasus pencurian dan pernikahan usia dini. Bahkan sampai kasus perkelahian, seperti dikatakan oleh Hamzani selaku Kepala Dusun Mensemat dan pengurus masjid Syuhada, untuk dua tahun ke belakang pernah dilakukan penangkapan terhadap 20 orang remaja Dusun Mensemat yang menjadi pelaku perkelahian di daerah Kecamatan Sajad. Fakta kondisi sosial remaja yang rentan terhadap krisis moral tersebut, menyebabkan masalah yang dihadapi menjadi lebih besar dan berat bagi remaja masjid Syuhada di Dusun Mensemat Desa Mekar Jaya khususnya. Karena sasaran remaja masjid Syuhada dalam membina akhlak adalah kelompok-kelompok remaja yang terdiri dari berbagai latar belakang baik dari lingkungan keluarga dan perilaku yang berbeda, sehingga remaja masjid Syuhada dalam melakukan pembinaan akhlak dengan bentuk kegiatan, menentukan pesan dan media yang digunakan serta bentuk komunikasi yang dipilih juga relatif berbeda sesuai dengan yang dibutuhkan.

Penjelasan di atas senada dengan pendapat Robin Mehall bahwa perencanaan komunikasi adalah dokumen tertulis yang menggambarkan segala hal yang harus dilakukan berhubungan dengan komunikasi dalam mencapai tujuan sehingga tujuan tersebut dapat dicapai, dan kepada siapa kegiatan komunikasi ditujukan dengan media baik dalam jangka 
panjang atau pendek, selanjutnya cara mengevaluasi hasil-hasil yang diperoleh dari kegiatan komunikasi (Yusuf Zainal Abidin, 2015: 89).

Berdasarkan hasil pembahasan di atas, dapat ditarik sebuah kesimpulan bahwa perencanaan komunikasi remaja masjid Syuhada dalam pembinaan akhlak remaja di Dusun Mensemat Desa Mekar Jaya terkait dengan strategi komunikasi yaitu pada tahap perencanaan komunikasi sangat diperlukan karena terbatasnya sarana dan prasarana komunikasi yang dimiliki oleh remaja masjid Syuhada sehingga perlu adanya sebuah perencanaan komunikasi yang efektif dalam dimensi strategi komunikasi.

2. Manajemen komunikasi yang dilakukan oleh remaja masjid Syuhada dalam pembinaan akhlak remaja di Dusun Mensemat Desa Mekar Jaya

Manajemen komunikasi itu sendiri cara membangun dan mengelola suatu hubungan baik dengan lisan atau tulisan sehingga segala aktivitas yang berkaitan dengan komunikasi dapat berjalan lancar dan baik. Manajemen bagi remaja masjid Syuhada merupakan sebuah proses perencanaan, pelaksanaan, dan pengevaluasian baik itu berupa ide atau gagasan dalam kegiatan pembinaan akhlak remaja di Dusun Mensemat Desa Mekar Jaya. Setiap usaha yang dilakukan pasti memerlukan manajemen yang baik dan matang sehingga usaha yang dilakukan akan efektif dan terstruktur, sama halnya dengan strategi komunikasi remaja masjid Syuhada dalam melakukan pembinaan akhlak remaja di Dusun Mensemat Desa Mekar Jaya.

Ide tersebut senada dengan pendapat Parag Diwan manajemen komunikasi merupakan proses penggunaan berbagai sumber daya komunikasi secara terpadu melalui proses perencanaan, pelaksanaan, dan pengevaluasian unsur-unsur komunikasi untuk mencapai tujuan yang telah ditetapkan (Yusuf Zainal Abidin, 2015: 131). Berdasarkan dari deskripsi di atas berkaitan dengan manajemen komunikasi bahwa adanya pelaksanaan dalam manajemen yang dibuat oleh remaja masjid Syuhada sebelum melakukan sebuah kegiatan. Tindakan manajemen komunikasi tersebut menurut Michal Kaye adalah cara individu atau manusia mengelola proses komunikasi melalui penyusunan kerangka makna dalam berbagai lingkup komunikasi, dengan mengoptimalisasi sumber daya komunikasi dan teknologi yang ada (Yusuf Zainal Abidin, 2015: 131).

Menurut Andew F. Sikula dalam bukunya Yusuf Zainal Abidi “Manajemen Komunikasi: Filosofi, Konsep dan Aplikasi", menjelaskan bahwa manajemen pada umumnya dikaitkan dengan aktivitas perencanaan, pengorganisasian, pengendalian, penempatan, pengarahan, pemotivasian, komunikasi, dan pengambilan keputusan. Perencanaan dilakukan sebelum kegiatan dilaksanakan dengan mempertimbangkan beberapa unsur seperti komunikator, pesan, media, komunikan dan efek. Pengorganisasian mencakup pengelompokan kegiatan kerja yang jelas dan tegas sesuai dengan lingkup pekerjaan dan pembagian tugas. Selanjutnya yaitu pelaksanaan atau aksi merupakan kegiatan yang membangkitkan dan mendorong semua persona organisasi agar berusaha untuk mencapai tujuan. Terakhir yaitu pengawasan adalah proses penetapan ukuran kinerja dari pengambilan tindakan untuk mendukung tercapainya tujuan organisasi (Yusuf Zainal Abidin, 2015: 131).

Berdasarkan pembahasan di atas, merujuk pada fokus penelitian terkait manajemen komunikasi remaja masjid Syuhada dalam melakukan pembinaan akhlak remaja di Dusun 
Mensemat Desa Mekar Jaya, maka dapat ditarik sebuah kesimpulan bahwa manajemen komunikasi yang dilakukan remaja masjid Syuhada cenderung ke arah proses manajemen dalam aktivitas komunikasi. Adapun proses manajemen dalam aktivitas komunikasi yaitu membuat perencanaan, pelaksanaan serta evaluasi aktivitas komunikasi. Melalui tiga proses manajemen ini, tergambar bagaimana bentuk manajemen komunikasi yang dilakukan remaja masjid Syuhada. Remaja masjid Syuhada membutuhkan manajemen komunikasi dalam melaksanakan strategi komunikasi yang digunakan dalam melakukan pembinaan akhlak remaja tersebut. Oleh sebab itu manajemen komunikasi sangat diperlukan melihat bagaimana proses komunikasi dan strategi komunikasi yang digunakan.

\section{PENUTUP}

Berdasarkan hasil pembahasan penelitian, maka strategi komunikasi Remaja Masjid dalam melakukan pembinaan kepada Remaja di Dusun Mensemat Desa Mekar Jaya, cenderung terlihat dari kegiatan, jenis informasi atau pesan serta media yang digunakan dalam melakukan pembinaan kepada Remaja di Dusun Mensemat Desa Mekar Jaya. Tindakan atau faktor yang terpengaruh dalam strategi komunikasi adalah perencanaan komunikasi, manajemen komunikasi serta faktor pendukung dan penghambat baik itu bersifat eksternal maupun internal.

Penelitian ini diharapkan dapat bermanfaat dalam meningkatkan ilmu dakwah umumnya, terutama secara khusus dapat mengembangkan keilmuan tentang ilmu komunikasi dan penyiaran Islam. Secara praktis, penelitian ini diharapkan dapat berguna bagai pengembangan dakwah berbasis pembinaan akhlak di Dusun Mensemat dan di daerah-daerah lainnya. 


\section{DAFTAR PUSTAKA}

Abidin, Yusuf Zainal. 2015. Manajemen Komunikasi; Filosofi, Konsep dan Aplikasi. Cet. 1. Bandung: Pustaka Setia.

Ayub, Moh. E. 1996. Manajemen Masjid Petunjuk Bagi Para Pengurus. Jakarta: Gema Insane Press.

Bob Andrian, 2017. "Pola Komunikasi Penyuluh Agama Islam Daerah 3 T Kecamatan Sajingan Besar Kabupaten Sambas." Tesis, Program Studi Komunikasi dan Penyiaran Islam, Program Pascasarjana UIN Gunung Djati Bandung Tahun.

Derajat, Zakiah. 1976. Ilmu Jiwa Dan Agama. Jakarta: Bulan Bintang.

Effendy, Onong Uchjana. 2006. Ilmu komunikasi Teori dan Praktek. cet, 1. Bandung: Remaja Rosdakarya.

2008. Dinamuka Komunikasi. cet 7. Bandung: Remaja Rosdakarya.

Faisal, Sanapiah. 1982. Metodologi Penelitian Pendidikan. Surabaya: Usaha Nasional.

https://www.detik.com/tag/kenakalan-Remaja/?sortby=time\&page=1 pada tanggal 15 Juli 2020 pukul 20.20 WIB.

Kementrian Agama RI, 2019. Al-Quraan dan Terjemah. Cet ke. 4. Tangerang, Forum Pelayanan Al-Quraan.

Moleong, Lexy J. 2009. Metodologi Penelitian Kualitatif. Bandung: Remaja Rosdakarya.

Resyana Wilda, 2014. "Strategi Komunikasi Perusahaan Umum Percetakan Uang RI (Perum Peruri) Dalam Pembinaan Pegawai", Skripsi, Jurusan Komunikasi dan Penyiaran, Fakultas Dakwah dan Ilmu Komunikasi UIN Syarif Hidayatullah Jakarta.

Shihab, M. Quraish. 2002. Tafsir Al-Mishbah; Pesan, Kesan, dan Keserasian Al-Quraan, cet. 1. Jakarta: Lentera Hati.

Soekanto, Soerjono. 2003. Sosiologi Suatu Pengantar. cet. 35. Jakarta: PT Raja Grafindo Perseda.

Subagyo, Djoko. 1991. Metode Penelitian dalam Teori dan Praktek. Jakarta: Reneka Cipta.

Wawancara dengan Hamzani pada hari Senin tanggal 11 Mei 2020 pukul 15-41 WIB. 